\title{
ECONOMICALLY USEFUL PLANTS OF SRI LANKA. PART VI.* EXPLOITATION OF SEED FATS OF MANGO AND RAMBUTTAN FOR THE PRODUCTION OF SOAP
}

\author{
Z. A. M. FAISAL, A.A.L. GUNATILAKA AND S. SOTHEESWARAN $†$ \\ Department of Chemistry, University of Peradeniya, Peradeniya, Sri Lanka.
}

AND

R. C. WIJESUNDERA

Oils and Fats Division, CISIR, Colombo 7, Sri Lanka.

(Date of receipt : 18.01.85)

(Date of acceptance : 15.08 .86 )

\begin{abstract}
Soaps have been prepared from the seed fats of mango and rambuttan. Their properties have been compared with those of commercial soaps. The results show that rambuttan seed, with its high fat percentage, could be exploited in the soap manufacture.
\end{abstract}

\section{Introduction}

Large quantities of mango and rambuttan seeds are discarded seasonally in Sri Lanka. In India, butter from mango seed fat is obtained and is used as food. The possibility of utilising mango seed butter in Sri Lanka has been suggested. ${ }^{4}$ In this paper, the soap obtained from the mango seed fat is compared with soaps available in the market. Soap from another seed which is discarded seasonally, rambuttan, has also been prepared.

\section{Results and Discussion}

The mango seed, rambuttan seed and coconut kernel fat percentages are given in Table 1. All are solid fats. The rambuttan seed has a fat content of $43 \%$ whereas the mango seed has a fat content of only $7 \%$. The fat content of rambuttan seeds is comparatively high and thus it could be economically exploited.

From Table 2, it can be seen that rambuttan seed fat has $50 \%$ saturated acids whereas the fat from coconut kernel has $92 \%$ saturated acids. The mango seed fat is not very different to that of rambuttan seed fat and has

- For Part V, see J. Natn. Sci. Coun. Sri Lanka 1982 10(2) : 221.

+ Present Address : Department of Chemistry, University of the South Pacific, Suva, Fiji. 
47\% saturated acids. Mango and rambuttan seed fats are very similar in having high content of oleanolic acid. These seed fats, though solids, are more unsaturated than the coconut kernel fat. However, the melting points of the mango and rambuttan fats are higher since they contain longer carbon chain fatty acids than those of coconut fat. Like the coconut kernel fat, the solid fats from mango and rambuttan seeds could be used in the soap manufacture. These soaps have been prepared by saponifying the fats using sodium hydroxide by the cold-process. ${ }^{2}$. The properties of these soaps have been compared with those of two common soaps available in the market. The results are given in Table 3. Though the matters insoluble in ethanol are high for the mango and rambuttan soaps, they are within the maximum weight per cent of 4 permitted for soft soaps.

Table 1. Fat Content of Coconut Kernel, Mango and Rambuttan Seeds.

\begin{tabular}{lcc}
\hline Source (Botanical Name) & M. Pt $\left({ }^{\circ} \mathrm{C}\right)$ & Fat (\%) \\
\hline Coconut Kernel (Cocos nucifera) & $21-25$ & 65 \\
Mango Seed (Mangifera indica) & $36-37$ & 6.8 \\
Rambuttan Seed (Nephelium lappaceum) & $37-55$ & 42.6 \\
\hline
\end{tabular}

The present study therefore, shows that the seed fats of mango and rambuttan can be used to manufacture soap. We suggest that with the escalating prices of coconut oil (and hence soaps), attempts should be made in Sri Lanka to collect the discarded seeds, extract fats and use them either separately or mixed with coconut oil in the manufacture of soap. Rambuttan seed, with its high fat content, could therefore be economically exploited in the soap manufacture.

\section{Experimental}

Mango and rambuttan seeds were collected during their respective seasons. The kernels were separately extracted with light petrol: The per cent fat is given in Table 1. The seed fats were saponified using sodium hydroxide. The amount of sodium hydroxide required to saponify a known quantity of the fat was calculated from the saponification value of each fat. ${ }^{3}$ The total fatty matter, substances insoluble in ethanol,free caustic alkali and total unsaponifiable matter were obtained for the mango soap, rambuttan soap and for two commercially available soaps (Sunlight and Lifebuoy) by the use of testing methods given by the Bureau of Ceylon Standards. The results are tabulated (Table 3). The $\mathrm{pH}$ values of these soaps are presented in Table 3. The acid components of the fats were analysed by gas chromatography (GC). The fats were converted to the methyl esters for GC analysis as follows: The fat $(100 \mathrm{mg})$ was refluxed with benzene $(1 \mathrm{ml})$, boron trifluoride in methanol $(20 \% ; 0.1 \mathrm{ml})$, and methanol $(2 \mathrm{ml})$ for $20 \mathrm{~min}$. Solvent was evaporated, 


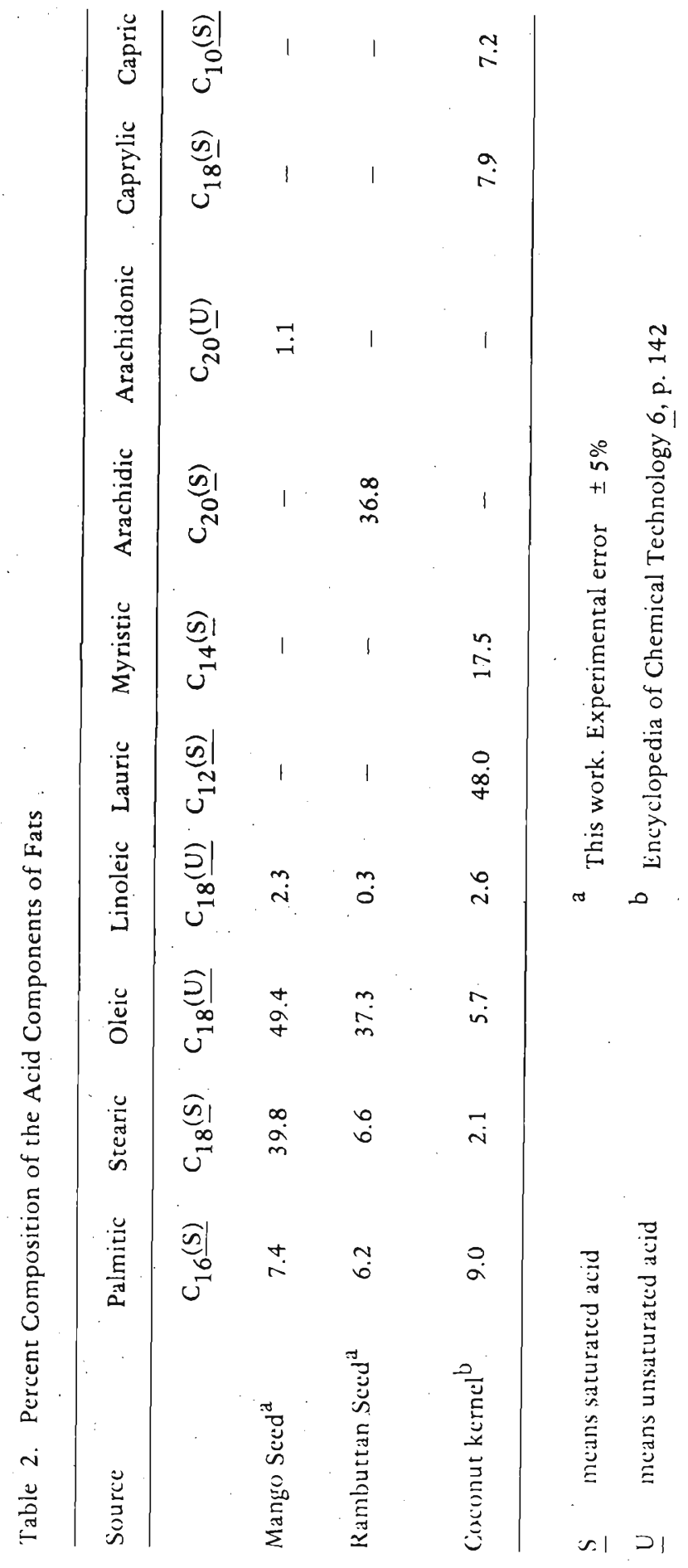


Table 3. Soap Specifications

\begin{tabular}{lcccc}
\hline $\begin{array}{l}\text { Specifications } \\
\text { Soap }\end{array}$ & $\begin{array}{c}\text { Rambuttan } \\
\text { Soap }\end{array}$ & $\begin{array}{c}\text { Sunlight } \\
\text { Soap }\end{array}$ & $\begin{array}{c}\text { Lifebuoy } \\
\text { Soap }\end{array}$ \\
\hline $\begin{array}{l}\text { Total fatty matter } \\
\text { percent by weight }\end{array}$ & 35.8 & 35.3 & 37.7 & 41.3 \\
$\begin{array}{l}\text { Matter insoluble } \\
\text { in ethangl percent } \\
\text { by weight }\end{array}$ & 4.7 & 4.4 & 0.5 & 0.4 \\
$\begin{array}{l}\text { Free caustic alkali } \\
\text { calculated as Na }{ }_{2}\end{array}$ & & & & \\
percent by weight & 0.2 & 0.2 & 0.2 & 0.3 \\
$\begin{array}{l}\text { Total unsaponified } \\
\text { matter percent by } \\
\text { weight }\end{array}$ & 1.7 & 1.7 & 1.0 & 1.2 \\
pH & 10.1 & 10.1 & 10.0 & 10.0 \\
\hline
\end{tabular}

water was added and the ester was extracted with ether. The ethereal layer was dried (anhydrous magnesium sulphate) and evaporation of ether gave the esters. GC analysis of the esters was carried out on a Varian model 2440 chromatograph equipped with a flame ionisation detector. The chromatograph was fitted with glass columns $(1.8 \mathrm{~m} \times 2 \mathrm{~mm}$ i.d) packed with $10 \% \mathrm{SP}$ 2340 coated on $100 / 200$ chromasorb $W$. The column was maintained at $190^{\circ} \mathrm{C}$. Argon was used as the carrier gas at a flow rate of $30 \mathrm{ml} \mathrm{min}{ }^{-1}$. The identification was by peak boosting and by comparing retention times. The fatty acids identified and their compositions are given in Table 2.

\section{Acknowledgements}

The authors thank the Natural Resources, Energy and Science Authority of Sri Lanka for research grants.

\section{References}

1. Ceylon Standard, $37:$ (1968) Specification for Soft Soaps.

2. Coconut Rescarch Institute, (1968) Leaflet No: 10.

3. Encyclopedia of Chemical Technology, $12: 574$.

t. SOTHEESWARAN. S., (1980), Karmantba, December issue, p.11. 